$8^{\text {th }}$ International Conference on Management, Economics and Humanities

7 - 9 December, $2018 \quad$ Barcelona, Spain

\title{
DETERMINANTS OF BEQUEST MOTIVE: A MICRO ANALYSIS
}

\author{
Dr. Shilpa. R. Samant* and Dr. P. K. Sudarsan** \\ Dhempe College of Arts and Science
}

\begin{abstract}
Household's savings are influenced by various motives. Despite extensive research on saving behavior, a large part of household saving motives still remain unexplained. A study of possible determinants of household saving motives and their influence is both practically and theoretically important. Saving motives are the reasons to save and are broadly classified in to Life-cycle, Precautionary and Bequest saving Motives. This article proposes to empirically investigate the effect of demographic, social and economic factors on the bequest motive at household level. Ordered probit analysis is used to find out association and influence of various factors on the bequest motive. The study considers six aspects of bequest motive for analysis. The study finds that age of the individuals, gender, education and wealth are the four main factors influencing the saving for the sub motives of bequest household saving motive followed by Family size. Locality, Dependency ratio, profession, income and employment status do not determine the saving for bequest motive. The study also finds out that there is more possibility of accidental bequest since no intentional savings are done by the households for bequest motive.
\end{abstract}

Keywords: Bequest motive, Demographic, Social and Economic factors, Probit analysis

\section{INTRODUCTION}

In the past two centuries, due to its increasing importance for national economies, household saving has been subject to extensive theoretical and empirical research. In spite of that, households' motivations for saving are still only partially explained and understood. We know certain variables that might be important as predictors for household saving such as income and age, but the underlying reasons for motivating saving process is an under researched topic which needs more attention. It is possible that there are certain motives which are common and dominant for all the individuals like Precautionary motive but its strength may differ based on certain factors like age, income, profession, etc. At the same time individuals may have heterogeneous saving motives which change from time to time, age to age and also depend on other socio economic conditions. This study proposes to empirically investigate the effect of Demographic factors like age, gender, locality, family size and dependency ratio, Social factors like profession and education and Economic factors like income, wealth and employment status on Bequest saving motive of households. A bequest motive exists if an individual accumulates assets during working years in order to provide his children with an 
$8^{\text {th }}$ International Conference on Management, Economics and Humanities

7 - 9 December, 2018

Barcelona, Spain

inheritance. It seeks to provide an economic justification for the phenomenon of gratuitous, intergenerational transfers of wealth. India is one of the emerging economies of the world today and the second fastest growing economy too. One important fact needs to be noticed here is that the household saving contribute a major part of domestic saving in India since individual saving is considered as a virtue at micro level. In India after new economic policy and globalization, economic situation changed influencing the people and their behaviour. Goa is considered as an emerging state of India with high propensity to save at household level. The study is carried out using household data collected from Goa. In the current study six aspects of bequest motive are taken in to consideration. They are saving to create asset for children, gift for children and relatives, to make jewelry for sister's/daughters marriage, business for children, Leave money for the next generation and for one's old age care.

\section{THEORETICAL FRAMEWORK}

Bequest motive explains the reasons people leave money behind when they die. The most common explanation for this is 'Altruism' in which emphasizes that the disponer gains some form of satisfaction from knowing that his/her heirs will enjoy their accumulated and inherited wealth like parents leaving a child the family home. Another common explanation is accidental bequest, developed by Yarri 1965 (qtd by Abel Andrew, 1985). Here since our lifetime is uncertain individuals hold precautionary savings to insure themselves from the risk of living too long. Finally, exchange bequest occurs where disponers engages in a sort of strategic exchange where in potential beneficiaries must render a (non marketable) service in exchange for the promise of inherited wealth. The most widely appreciated model of exchange bequest was published by Bernherm, Summers and Shleifer (1985).

Which bequest motive theory most realistically represents the intentions of estate planners is not so clear. Various attempts were made to test these theories empirically but mixed results are shown by the researchers. Hence bequest motive is the much- debated motive. There have been various contradictory findings even with regards to amount of wealth accumulation on account of bequest motive. It ranges from $3 \%$ to $80 \%$ of the total wealth accumulation.

While collecting subjective data on the matter, the bequest motive is primarily found among the upper part of the income and wealth distribution. Various studies also support that a very small part of the population regards bequest as an important reason to save. Lindqvist (1981) reported that only $3 \%$ of his sample said that leaving bequest was the most important saving motive. The same frequency was found in the Survey of Consumer Finances in 1992: while 5\% of the sample indicated that inheritance was among their top five reasons for saving (Carroll, 1998). Modigliani (1988) cited several surveys about saving motives, which all give little support to the bequest motive, and he also found the bequest motive to be increasing with income and wealth. Lack of dissaving among the elderly seemed more to be caused by precautionary motives, so that decumulation takes place at a 
$8^{\text {th }}$ International Conference on Management, Economics and Humanities

7 - 9 December, 2018

Barcelona, Spain

very old age. Hurd (1999) found some support for this view. The data from the Health and Retirement study was used and the Asset and Health Dynamics of the Oldest old (AHEAD) and found that respondents anticipated substantial dissaving at advanced old age. Much bequest might therefore be accidental. Bernheim et. al. (1985) found some support for their notion of a strategic bequest motive. They found that contact between parents and children are much higher in families where the elderly parent has a substantial amount of bequeathable wealth to offer.

This has been supported in a study by Dynan, Skinner and Zeldes (2000) who found that households with higher lifetime income leave a larger bequest. Alessie, Lusardi, and Kepteyn $(1995,1999)$ analyzed Dutch data and found income, wealth and home ownership to be strongly associated with bequest. They also found that the bequest motive is more important among the older household than among the younger. This means motives might change over the life-cycle.

Carroll (1998) tested several alternative models and found that the behavior of the rich can best be explained by a model in which consumers regard the accumulation of wealth as an end in itself ( a capital spirit model). This model implies that wealthy people drive utility either directly from the ownership of wealth, indirectly from the activities that lead to wealth accumulation or from utility derived from the power or social status tied to the ownership of high wealth. An alternative model, which did not receive much support in Carroll's study, is the 'Dynasty' model of Barro (1974), which implies that wealthy save mainly for the benefit of their heirs. Carroll (1998) also pointed to the fact that it is difficult for the super-rich not to accumulate assets. Extremely rich people might also be subject to consumption satiation. The above literature makes it clear that bequest motive is the most debated motive right from its existence, where some researchers refute the actual existence of pure bequest motive as such since it may be just the saving under precautionary motive which ends up in to an accidental bequest since the lifespan of an individual is not certain and if precautionary saving remains unused and then it is carried forward in the form of inherited wealth. Similarly many researchers have got even contradictory results in their studies with regards to even the magnitude of saving under bequest motive. At the same time, people's behavior also differs as far as their choice of leaving bequest is concerned hence researchers have developed various models to explain this, but no one established rule can be applied to bequest motive. The main objective of this study is to find out the determinants of this saving motive, taking in to account the Demographic, Social and Economic factors.

In the current study the following aspects of bequest motive are taken in to consideration.

i. Asset for children: This aspect of the bequest motive includes saving done by the people in order to create assets may be in the form of house, flat, land ownership and other investments which they would like to pass on to their children in the form of inheritance. ii. Gift for children and relatives: Saving done in order to be self sufficient and to have freedom to give gifts or valuables to their children and/ or relatives for various occasions. This type of transfer is also called as inter vivos transfers by some 
$8^{\text {th }}$ International Conference on Management, Economics and Humanities

7 - 9 December, 2018

Barcelona, Spain

researchers. iii. Business for children: Here the savings are done in order to set up or expand the existing business to pass it on to the next generation for them to carry it forward. It is done for creating a security for one's next generation. iv. Old age care: The saving done in order to make sure that one gets the care and needed attention in one's old age from his/ her children and/ or relatives.

v. vi.

to make jewelry for sister's/daughters marriage: Households save in order to make provision for the purchase of jewelry for the girls in the family especially during their marriage. This is an important aspect of Indian marriages.

vii. Leave money for the next generation: Here the savings are done in order to pass on the wealth for the next generation and to safeguard their future.

\section{METHODOLOGICAL FRAMEWORK}

This research is a micro level study and the data is collected from the respondents through questionnaires by personal visits to the households. The sample for the main study consisted of 300 households in Goa (India). Test -Retest' method has been used to test the validity and reliability of the instrument since the questionnaire included the scale to gauge respondent's preference towards various saving motives. In order to ensure randomness, a multistage random sampling technique is used to select the sample.

The study calculated the wealth index by using principle component analysis. Two components of wealth were extracted by using principle component analysis and these two components are used for analysis. The first component includes the type of house the respondents stay in and the number and type of vehicle they own. This wealth can be called as 'Economic Status wealth' since these two things depict the economic status of the people and is called 'Wealth 1 ' in the study and second component takes in to consideration agricultural land ownership, Plot/s owned besides their residence and its location. This component is considered as 'Asset wealth' since this type of wealth is an asset and is referred to as 'Wealth 2 ' in the study.

Ordered probit analysis is used to find out association and influence of various factors on the components of bequest saving motive. Since the data collected in the study is much qualitative in nature, mainly the dependent variable in this study. The calculation of dependency ratio has been done taking in to consideration number of earning and nonearning members in a household.

The Ordered Probit model used in this study is in the following form: $\mathbf{y i}^{*}=\boldsymbol{\beta} 0+\mathbf{x} 1 \mathbf{i} \boldsymbol{\beta} 1+\mathbf{x} \mathbf{2} \mathbf{i}$ $\boldsymbol{\beta} 2 \ldots \mathbf{x k i} \boldsymbol{\beta} \mathbf{k}+\boldsymbol{\varepsilon} \mathbf{i}$ yi*=latent variable using the scale $1,2 \ldots .5$, one being the least important and the 5 being most important. $\mathrm{X} 1 \mathrm{i}, \mathrm{X} 2 \mathrm{i}, \mathrm{Xki}$ are the independent variables as the factors determining bequest motives. Three separate ordered probit models are estimated for categories of independent variables, viz, demographic factors, social factors and economic 
$8^{\text {th }}$ International Conference on Management, Economics and Humanities

7 - 9 December, $2018 \quad$ Barcelona, Spain

factors. For demographic factors $\mathrm{X} 1 \mathrm{i}, \mathrm{X} 2 \mathrm{i}, \mathrm{Xki}$, are age, gender, locality, family size, etc. For social factors $\mathrm{X}_{1} \mathrm{i}, \mathrm{X} 2 \mathrm{i}$, are education and profession. For Economic factors $\mathrm{X} 1 \mathrm{i}, \mathrm{X} 2 \mathrm{i}, \mathrm{Xki}$, are income, employment and wealth.

\section{IV.DEMOGRAPHIC, SCIAL AND ECONOMIC FACTORS 1. Demographic factors and Bequest Motive. i. Age and Bequest Motive}

Life cycle hypothesis says that average propensity to save varies significantly from a minimum at the early and late years to a maximum and again comes down with retirement where people dissave. But later researchers showed that at the retirement and thereafter, people may not compulsorily dissave. They may be motivated to save on account of bequest motive. There is a wide range of total amount of income saved given by researchers on account of bequest motive. Researchers also vary in their opinion as to what type of bequest is considered as the most important; accidental, altruistic or based on dynasty model. Sometimes saving is done in order to safeguard one's old age needs and Hence age can be an important determinant of saving for Bequest motive. ii. Gender and Bequest Motive

Males and females may have different saving patterns as they may differ on their saving motives hence this demographic factor is considered in the study. It is usually found that financial decisions in the family are taken by either head of the family or the elder members of the family which may or may not include females in the family. So difference in saving decision for various aspects of bequest motive is possible. iii. Locality and Bequest Motive Bequest motive is considered to be an important motive by some researchers where as others are of the opinion that it may become important to people who own their business or those who have sufficiently accumulated wealth. Locality may play an important role in saving decisions since socio economic environment in rural and urban areas differ which may affect the mindset of the people towards saving motives. iv. Family size and Bequest Motive It refers to total number of people residing under one roof and eating from the same kitchen that is considered as a 'household' in the present study. It is possible that a joint family running the business of their own might consider it customary to pass on their wealth to the next generation or it is also possible that bigger size family might make it difficult to think about accumulating wealth and passing it on to their next generation. Hence considering family size as a factor influencing saving decision becomes important. v. Dependency ratio and Bequest Motive

Usually if the dependency ratio is high, much of the income may be spent on satisfying the needs of the dependents so it is possible that not much remains in the hands of the earner in order to save. The earner may like to save in order to pass on the wealth to the next 
$8^{\text {th }}$ International Conference on Management, Economics and Humanities

7 - 9 December, $2018 \quad$ Barcelona, Spain

generations but satisfying their present needs may become his/her priority. Secondly it is possible that saving for precautionary reasons may be considered more important here since the responsibility of more people on income earner. So also if the household is wealthy and/or already has inherited wealth then passing that wealth to the next generation may become obvious so it may not become a purposeful motive of saving.

\section{Social factors and Bequest Motive}

Education and profession are the two social factors considered in this study $\mathbf{i}$. Education and bequest motive

Education affects the mindsets of the individuals, so also his economic and social behavior. It is thought that it can also affect the saving behavior and in turn saving motives of the individuals and hence it is considered in the present study as one of the social factors. Education is expected to have positive effect on earning capacity of an individual which in turn can increase individual's capacity to save for future. ii. Profession and Bequest Motive. Profession is another social factor which was thought to have influence over saving motives along with the saving quantum. Since different professions differ in risk factors, earning capacity, future prospects, competition level, and opportunities it can affect different saving motives. It is possible that along with the traditions and customs even the family profession may be passed on to the next generation.

\section{Economic factors and Bequest Motive.}

Income, employment status and wealth are the economic factors considered in the study. $\mathbf{i}$. Income and Bequest Motive

Income is one of the prerequisite to accumulate wealth. Higher the income higher will be individual's capacity to save and invest. Higher saving and investment leads to capital accumulation. Life -cycle hypothesis proposes that saving varies according to the stages of life cycle; to begin with when the income is low at the start of the working career the saving also happens to be less, later as income increases saving also rises and reaches its peak and then with the retirement there is decline in both income and simultaneously saving. Later various studies confirmed and contradicted and also contributed through their empirical evidences to these theories. Many studies revealed that income and wealth together influence household saving It is also found that business families show more savings for bequest motive. So it is interesting to find if there exists any connection between level of income and components of bequest motive.

\section{ii. Employment and bequest motive}

Employment is the second economic factor taken in to consideration in this study.

Employment conditions may affect saving behavior through affecting saving motives. iii. Wealth and bequest motive. 
$8^{\text {th }}$ International Conference on Management, Economics and Humanities

7 - 9 December, $2018 \quad$ Barcelona, Spain

Many researchers have found a close association between wealth and bequest left for the next generation since wealthy people leave property and wealth for their heirs.

\section{RESULT AND DISCUSSION}

The study found that just 28 out of 300 respondents i.e. $9.33 \%$ said that they would like to leave a considerable bequest to their child/ children if they take good care of them when they get old, 98 respondents i.e. $32.67 \%$ said that they would like to leave bequest to their child/ children irrespective of the way they take care of them when they are old, 145 i.e. $48.33 \%$ of the respondents did not have any preconceived plan leaving bequest to their children and 25 i.e. $8.33 \%$ of them do not intend to leave any bequest to their children with 4 respondents i.e. $1.34 \%$ did not comment on leaving the bequest to their heir. From this it appears that majority of the respondents i.e. 56.66 ( 48.33 and 8.33 ) did not have a definite tilt towards saving for bequest motive. Along with this, respondents in the age group of above forty mentioned that good education to their children is a key to future better standard of living which they have provided hence there is no need to keep any wealth for their children in the form of bequest. Hence it can be said that this study finds that people don't intend to save in order to pass on their wealth but accidental bequest is possible. Similarly respondents who intend to save for future generation, want to do it without expecting anything in return. This favors altruist model of bequest in this study.

Table no.1 depicts the result of probit analysis showing the coefficient and $z$ values. The table includes only those factors which are found to be influencing the various aspects of bequest motive. The remaining factors are not statistically significant and show no influence on the aspects of bequest motive.

The results shown in the table 1 depicts that age determines savings to create assets for children, to make jewelry for daughter/sister in wedding, to set up/ expand business to pass on and to leave money for the next generation.

It can be also seen that there is a dependence of saving to be utilized to create assets like house, land, etc. for the children and to set up/ expand business to pass on to the next generation on gender.

It is found that family size influences the savings to make jewelry for daughter/sister in wedding.

Education is found to influence the saving in order to set up/ expand business to pass on to the next generation.

The results also show that the first component of wealth determines saving made to create assets for children/ relatives.

Table 1-Probit Analysis of Demographic, Social and Economic Factors and Aspects of Bequest Motive. 
$8^{\text {th }}$ International Conference on Management, Economics and Humanities

7 - 9 December, $2018 \quad$ Barcelona, Spain

\begin{tabular}{|c|c|c|c|c|c|c|}
\hline \multirow[b]{2}{*}{ Components } & \multicolumn{3}{|c|}{ Demographic factors } & \multirow{2}{*}{$\begin{array}{c}\text { Social factor } \\
\text { Education }\end{array}$} & \multicolumn{2}{|c|}{ Economic factors } \\
\hline & Age & Gender & Family size & & Wealth 1 & Wealth2 \\
\hline \multirow{2}{*}{$\begin{array}{l}\text { Create assets } \\
\text { for children. }\end{array}$} & -.2634 & -.3360 & .0789 & .0471 & -.2524 & .0259 \\
\hline & $\left(-4.973^{* * *}\right)$ & $(-2.516 * *)$ & (.7279) & (.7749) & $-2.973 * * *$ & .9002 \\
\hline \multirow{2}{*}{$\begin{array}{l}\text { Gift for } \\
\text { children and } \\
\text { relatives. }\end{array}$} & -.0688 & .0434 & .1565 & .0537 & .0613 & .0166 \\
\hline & $(-1.336)$ & $(.3343)$ & $(1.457)$ & (.8936) & .7429 & .5812 \\
\hline \multirow{2}{*}{$\begin{array}{l}\text { Jewellery } \\
\qquad \text { for } \\
\text { daughter/sister } \\
\text { in wedding. }\end{array}$} & -.2226 & -.1023 & .1876 & -.0822 & -.0208 & .0318 \\
\hline & $\left(-4.100^{* * *}\right)$ & $(-.7496)$ & $\left(1.724^{*}\right)$ & $(-1.339)$ & -.2472 & 1.092 \\
\hline & -.2381 & -.2909 & .0961 & $-.1798 * * *$ & -.0376 & .1055 \\
\hline $\begin{array}{l}\text { Set up/ expand } \\
\text { business } \\
\text { on. to pass }\end{array}$ & $\left(-4.244^{* * *}\right)$ & $\left(-2.091^{* *}\right)$ & $(.8625)$ & $(-2.842)$ & -.4371 & $3.560 * * *$ \\
\hline \multirow{2}{*}{$\begin{array}{l}\text { Leave money } \\
\text { for the next } \\
\text { generation. }\end{array}$} & -.0993 & -.0047 & .1248 & -.0829 & -.0284 & .0597 \\
\hline & $\left(-1.918^{*}\right)$ & $(-.0360)$ & $(1.163)$ & $(-1.377)$ & -.3437 & $2.091^{* *}$ \\
\hline \multirow{2}{*}{$\begin{array}{l}\text { For children to } \\
\text { safeguard one's } \\
\text { old age care. }\end{array}$} & .0059 & .0190 & .1656 & -.0989 & .0802 & -.0116 \\
\hline & (.1127) & $(.1422)$ & (1.499) & $(-1.612)$ & .9453 & -.3957 \\
\hline
\end{tabular}

***Significant at 0.01 level. ** Significant at 0.05 level. *Significant at 0.1 level.

Figures in the brackets indicate $z$ values.

As far as the second component of wealth is concerned the results from table depicts that saving to set up/ expand business to pass on to the next generation and saving to leave money for next generation is influenced by the second component of wealth.

Locality, dependency ratio, profession. Income and employment status does not show any influence on any of the bequest sub motives.

\section{Vi. CONCLUSION}

Age and gender are two important demographic factors influencing bequest motive. Age determines saving with a motive to create assets for children, jewelry for daughter/sister's wedding, to set up/expand business to pass on and to leave money for the next generation. 
$8^{\text {th }}$ International Conference on Management, Economics and Humanities

7 - 9 December, $2018 \quad$ Barcelona, Spain

Similarly gender is identified as an important factor influencing saving to create assets for children and set up/ expand business to pass on and family size with a motive to make and give jewelry for daughter/sister's wedding.

Education is found to influence the motive to save in order to set up/ expand business to pass on. Economic factors like wealth1 and wealth 2 influence saving with a motive to create assets for children/relative and to set up/expand business to pass it on to the next generation. The study also finds out that there is more possibility of accidental bequest since no much intentional savings are done by the households for bequest motive.

References:

Ando A and Modigliani F (1963): 'The Life-cycle Hypothesis of Saving: Aggregate Implicates and Tests', American Economic Review, Vol. 53, pp. 55-84, September.

Abel Andrew (1985): 'Precautionary Saving and Accidental Bequests', The American Economic Review, Vol. 75 (4), pp. 777 - 791, September.

Alessie R J M, Lusardi A and Kapteyn A (1995): 'Saving and Wealth Holdings of the Elderly', Ricerche Economiche, Vol.49, pp. 293-315.

Alessie R J M, Lusardi A and Kapteyn A (1999): 'Saving after Retirement: Evidence based on three different measures', Labour Economics, Vol.6, pp. 277-310.

Barro R J (1974): 'Are government bonds net worth?', Journal of Political Economy, Vol. 81, pp. 1095-1117.

Bernheim Douglas B, Shleifer Andrei and Summers Lawrence H (1986): 'The Strategic Bequest Motive', Journal of Labour Economics, Vol. 4 (3), Part 2: The Economic Rewards, pp. S151S182, July.

Carroll Christopher D (1997): 'Buffer stock saving and the life cycle/permanent income hypothesis', The Quarterly Journal of Economics, Vol. 112 (1), pp. 1 - 55, February. Dynan Karen E, Skinner Jonathan and Zeldes Stephen P (2004): 'Do the Rich Save More?', Journal of Political Economy, Vol. 112 (2), pp.397- 444, April.

Hurd Michael D (1990):'“Research on Elderly: Economic status, retirement, Consumption and Savings', Journal of Economic Literature, Vol. 28 (2), pp. 565-637, June.

Lindqvist Alf (1981): 'A note on determinants of household saving behaviour', Journal of Economic Psychology, Vol. 1(1), pp.39- 